\title{
ESTIMATE OF GROUNDWATER RECHARGE BASED ON WATER BALANCE IN THE UNSATURATED SOIL ZONE
}

\author{
Davi de Carvalho Diniz Melo ${ }^{(1) *}$, Edson Wendland ${ }^{(2)}$ e Rafael Chaves Guanabara ${ }^{(3)}$
}

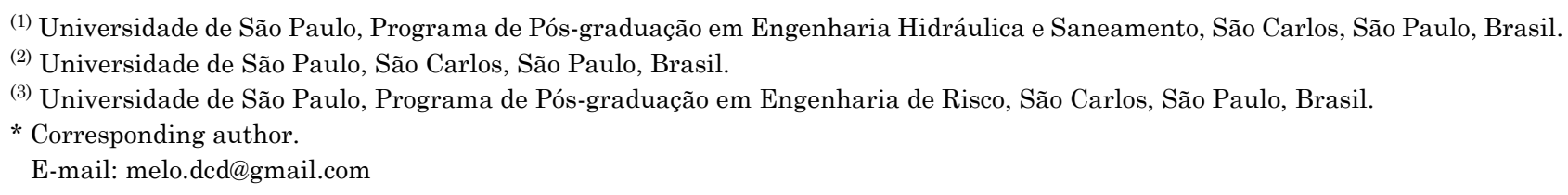

\begin{abstract}
Ground water management depends on the knowledge on recharge rates and water fluxes within aquifers. The recharge is one of the water cycle components most difficult to estimate. As a result, despite the chosen method, the estimates are subject to uncertainties that can be identified by means of comparison with other approaches. In this study, groundwater recharge estimates based on the water balance in the unsaturated zone is assessed. Firstly, the approach is evaluated by comparing the results with those of another method. Then, the estimates are used as inputs in a transient groundwater flow model in order to assess how the water table would respond to the obtained recharges rates compared to measured levels. The results suggest a good performance of the adopted approach and, despite some inherent limitations, it has advantages over other methods since the data required are easier to obtain.
\end{abstract}

Keywords: SPA model, Guarani Aquifer, groundwater, soil-plant interaction.
RESUMO: ESTIMATIVA DE RECARGA SUBTERRÂNEA POR MEIO DE BALANÇO HÍDRICO NA ZONA NÃO SATURADA DO SOLO

O gerenciamento dos recursos hídricos subterrâneos depende do conhecimento a respeito das taxas de recarga e dos fluxos que ocorrem nos aquíferos. A recarga subterrânea é um dos componentes do ciclo hidrológico mais complexo de ser obtido. Em razão disso, as estimativas obtidas, independentemente do método empregado, estão sujeitas a incertezas que podem ser identificadas por meio da comparação entre métodos. Neste trabalho, avaliou-se a recarga subterrânea para diferentes usos agrícolas com 


\begin{abstract}
base no balanço hídrico da zona não saturada do solo. A avaliação foi feita, primeiramente, por meio da comparação com estimativas obtidas pelo método da Flutuação da Superfície Livre (Water Table Fluctuation). Em seguida, as taxas computadas foram usadas como entradas num modelo transiente de fluxo com intuito de verificar sua consistência por meio da comparação com dados de níveis medidos em campo. Os resultados indicaram que o método aplicado apresentou desempenho satisfatório e, apesar de limitações inerentes, evidenciaram a vantagem de sua utilização em relação a outras técnicas por requerer dados de maior facilidade de obtenção.
\end{abstract}

Palavras-chave: modelo SPA, Aquífero Guarani, água subterrânea, interação solo-planta.

\section{INTRODUCTION}

The Guarani Aquifer System (GAS) is one of the most important water sources in South America, with an estimated volume between 25,000 and $37,000 \mathrm{~km}^{3}$ (OEA, 2009). The GAS area is distributed in Brazilian $\left(736,000 \mathrm{~km}^{2}\right)$, Argentinian $\left(228,200 \mathrm{~km}^{2}\right)$, Paraguayan $\left(87,500 \mathrm{~km}^{2}\right)$ and Uruguayan $\left(36,200 \mathrm{~km}^{2}\right)$ territories (Gastmans et al., 2010). In Brazil, it is present in the states of Goiás $\left(55,000 \mathrm{~km}^{2}\right)$, Mato Grosso $\left(26,400 \mathrm{~km}^{2}\right)$, Mato Grosso do Sul $\left(213,200 \mathrm{~km}^{2}\right)$, Minas Gerais $\left(51,300 \mathrm{~km}^{2}\right)$, São Paulo $\left(155,800 \mathrm{~km}^{2}\right)$, Paraná $\left(131,300 \mathrm{~km}^{2}\right)$, Santa Catarina $\left(49,200 \mathrm{~km}^{2}\right)$, and Rio Grande do Sul $\left(157,600 \mathrm{~km}^{2}\right)$ (Araújo et al., 1999).

GAS is essentially confined or semi-confined, with outcrop areas, where the recharge occurs, corresponding to approximately $10 \%$ of the total area (Wendland and Rabelo, 2010). In the State of São Paulo, approximately $15 \%$ of the $155.800 \mathrm{~km}^{2}$ correspond to outcrop zone. The concentration of wells is also highest in this state, accounting for $90 \%$ of the water extraction in Brazilian territory (OEA, 2009).

Understanding recharge mechanisms and water flow in this system is extremely important for a sustainable management of the water resources. However, groundwater recharge is one of the most difficult-to measure components of the hydrological cycle, once there are no direct measuring methods. Various techniques are described in the literature (Scanlon et al., 2002; 2006; De Vries and Simmers, 2002), but they all have limitations and uncertainties, making a comparison with estimates of different methods necessary. Among these, water balance seems advantageous, for not being limited to only one of the soil zones (Healy et al., 2007).

The computational modeling of recharge mechanisms and flow allows an understanding of the processes, and provides information that can be used in the decision making process (Wendland and Rabelo, 2010; Rodríguez et al., 2013). However, the recharge estimates and flow simulation must be validated for the effective conditions of the Guarani Aquifer System.

For this validation, data measured in situ in one of the areas with representative characteristics of the GAS recharge zone were used: Ribeirão da Onça watershed (ROW), in which the research group of the Computational Hydraulics Laboratory (Laboratório de Hidráulica Computacional - LHC) continually performs biweekly monitoring of the levels in the unconfined aquifer (Wendland et al., 2007; Lucas et al., 2012; Wendland et al., 2014), and the data can be used to quantify these processes.

The hypothesis is that the recharge process can be simplified by the mass balance represented by the water balance method (WBM) in an unsaturated zone. The main objective is to validate the WBM. These estimates were verified by the response analysis of a computational model of transient flow for the study area.

\section{MATERIAL AND METHODS}

\section{Study area}

The experimental area in the Ribeirão da Onça watershed (ROW) is located in the city of Brotas, SP (latitudes $22^{\circ} 10^{\prime}$ to $22^{\circ} 15^{\prime} \mathrm{S}$ and longitudes $47^{\circ} 55^{\prime}$ to $48^{\prime} 00^{\prime} \mathrm{W}$ ) (Figure 1). The Ribeirão da Onça is one of the contributors to the Jacaré-Guaçú River, an affluent of the Tietê River. One of its most interesting characteristics is its location in an outcrop area of GAS.

Close to the center of the watershed $(\sim 7 \mathrm{~km})$ is the Center of Water Resources and Applied Ecology (Centro de Recursos Hídricos e Ecologia Aplicada - CRHEA/USP), where a weather station is installed. The data measured show that the average annual temperature in the region, between 1970 and 2013 , was $20.5^{\circ} \mathrm{C}$, and the average annual rainfall in the same period 1,500 mm; and according to Köppen's classification, this region has a humid subtropical climate with rainy summers and dry winters (Cwa).

\section{Land use}

The Ribeirão da Onça watershed (ROW) is located in a rural area used for agriculture and animal husbandry. For the past 13 years, an increase in plantation areas, 


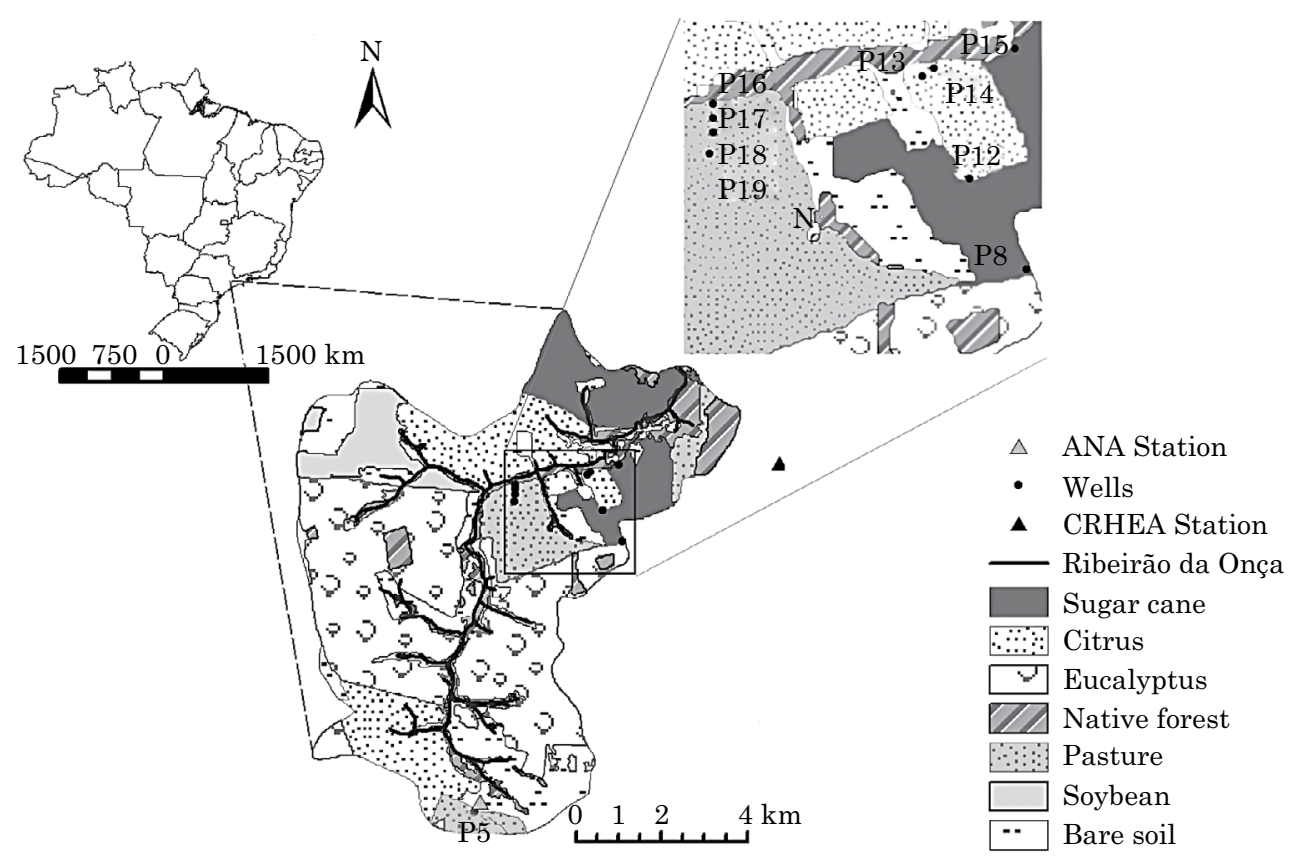

Figure 1. Location of the Ribeirão da Onça watershed, monitored wells and land use in the study area in 2011, locations of the rainfall station ANA and weather station CRHEA. Adapted from Manzione et al. (2011).

especially of sugar cane and eucalyptus, has been observed. Nowadays, the land use consists of pasture, native forest, and sugar cane, eucalyptus, citrus (orange and/or lemon), and soybean plantations. On the map drawn in 2011 (Figure 1), these crops accounted for 10, $11,35,15$ and $5 \%$ of ROW, respectively

Classification presented in figure 1 (Manzione et al., 2011) comprises a period during which some of the areas where going through a change in the land use. Therefore, the areas without vegetation (17\% in figure 1) did not remain bare in the seven years of this research. This is the case for the area in the southern part of ROW, where, since then, orange orchards were planted.

\section{Data collection}

Rainfall and temperature data were provided by the weather station CRHEA. Not only rainfall data from the afore-mentioned station were used, but also from the National Waters Agency (Agência Nacional de Águas - ANA), located in the southern part of ROW (Figure 1).

Phreatic levels (PL) in the unconfined aquifer were measured in monitoring wells installed in the watershed. Other hydrogeological data, required to construct the model, are hydraulic conductivity, specific yield and thickness of the aquifer. Specific aquifer yield in the ROW was determined by Gomes (2008), by analyzing undisturbed samples from five points in the ROW at three different depths (between 3 and $19 \mathrm{~m}$ ). At each point, the depths corresponded to a respective variation range of the phreatic level.
Planialtimetric and drainage data were obtained from fluvial drainage maps with the respective terrain contour lines and images from Shuttle Radar Topographic Mission (SRTM). In addition to the maps, in situ visits were performed to determine the altitude of some of the affluent springs of Ribeirão da Onça. SRTM image was processed in a Geographical Information System (GIS) to make the digital elevation model (DEM) for the study area. In the GIS, altitudes were extracted and translated into the input format of the computational model.

\section{Conceptual model}

General physical and hydrogeological properties of the area indicate that there is only one hydrostratigraphic unit. This allows a simplification of the real system, making the numerical representation of the aquifer non-confined region appropriate, as proposed in this paper.

The conceptual model adopted assumes that there are no confinement regions in the ROW. The boundaries in the subterranean model were considered coincidental to the topographical divisors in the watershed and $2^{\text {nd }}$ type conditions (Neumann) were applied to them. The $3^{\text {th }}$ boundary condition (Robin) was applied, specifying the water levels throughout the drainage network.

\section{Computational model}

The numerical model was built using the computational package SPA (Simulating Processes in Aquifers) (Wendland, 2003; Wendland et al., 
2013). The software allows a permanent and transient simulation of the groundwater flow problems and of the solute transportation in tridimensional domains in saturated and unsaturated porous means. The model uses the finite element method (FEM) to discretize the domain and solve the flow equations. It is composed of modules with specific functions:

a. Aquifer Model Constructor (Construtor de Modelos de Aquíferos - CMA): builds the finite element mesh and assigns the geological and hydrogeological parameters;

b. Aquifer Model Test (Verificador de Modelos de Aquíferos - VMA): optimizes the possible errors and problems in the mesh;

c. Groundwater Flow (Fluxo de Águas Subterrâneas - FAS): simulates the groundwater flow in a permanent regime;

d. Pollutant Transport (Transporte de Poluentes $\mathrm{TP})$ : simulates the transient flow and/or solute transport; and

e. Aquifer Processes Visualizer (Visualizador de Processos de Aquíferos - VPA), GIA and XPLT: generates images from the model and simulation results.

The pre-processing algorithms implemented in SPA generate unstructured networks in heterogeneous means based on Delaunay's triangulation and advancing front (George and Seveno, 1994). The resulting equations systems are solved by matrix storage techniques, iterative (PCG - Preconditioned Conjugate Gradient) and direct (SUPER-LU) algorithms (Barrett et al., 1994).

\section{Model calibration}

To calibrate the model, hydraulic conductivity and specific yield parameters were manually adjusted based on the comparison between hydraulic charge results simulated and the ones measured during the period between 2004 and 2011. The initial values of such parameters were based on estimates presented by Sracek and Hirata (2002) and Gastmans and Kiang (2005).

\section{Groundwater recharge estimation}

Groundwater recharge was estimated by the water balance and compared to the results of Lucas et al. (2012), who used the free surface variation method (Water Table Fluctuation - WTF) (Healy and Cook, 2002). The method was chosen based on two criteria: recharge spatialization and applicability for future scenarios. Even though WTF also supplies specialized information, they depend on monitoring the well distribution and can only be applied to the points where the wells are located.

Water balance allows estimating the recharge for the entire area under study and for each type of vegetation cover and/or soil. In this study, recharge was estimated considering the different types of land use listed in item Land Use. Monthly recharge (R) was calculated as being a part of the potential monthly recharge $\left(R_{p}\right)$ (Melo, 2013), given by the residual balance in the surface layer, corresponding to the soil root zone:

$R_{P}=P-E T_{r}-E s-\Delta S_{z n s}$

Eq. 1

where $P$ is the monthly rainfall, $E T_{r}$ the real evapotranspiration, $E s$ the surface and subsurface drainage, and $\Delta \mathrm{S}_{\mathrm{znz}}$ the storage variation in the unsaturated zone. The rainfall used in the balance is given by the weighted average between the measurements of CRHEA and ANA stations, weighing the distances between the station and the respective vegetation-covered area.

Real evapotranspiration $\left(\mathrm{ET}_{\mathrm{r}}\right)$, described in detail by Melo (2013), was estimated from the corrected potential evapotranspiration $\left(\mathrm{ETP}_{\text {cor }}\right)$ and average $\mathrm{K}_{\mathrm{c}}$ values per crop (Allen et al., 1998). $\mathrm{ETP}_{\text {cor }}$ was estimated by correction of the potential evapotranspiration calculated by Thornthwaite's equation, as proposed by Medeiros et al. (2012).

For the study area, no experimentally measured surface drainage data were available for the analyzed period. The data used in this paper are from the hydrological model for ROW, calibrated by Machado et al. (under review) using JAMS modeling system.

Unsaturated zone's storage variation was calculated as being a difference between the water content in the soil regarding the month in question and the previous one. A model for the balance was implemented by Melo (2013), considering that each area with a different soil use has a maximum water retention capacity, depending on the root-zone extension within the unsaturated zone (Smax). The idea underlying this approach is to represent water storage and flows by means of linear reservoirs, similar to the ones applied by Raneesh and Thampi (2013) and Kwon et al. (2012).

In summary, the application of the algorithm results in the balance shown in figure 2 . Since rainfall $\mathrm{P}$ is the only water input in the balance, water residual $\mathrm{db}$ that enters reservoir $R_{\text {soil }}$ will cause an increase or decrease in reservoir water level. If the $R_{\text {soil }}$ volume is greater than Smax after adding $\mathrm{db}$, there will be a potential recharge value, given by equation 1 .

\section{RESULTS AND DISCUSSION}

\section{Numerical model construction - CMA Module}

The elements and nodes that compose the structure and contours of the model are shown in 
figure 3. To create the finite element mesh, points coinciding with the contours were defined, spaced at least $200 \mathrm{~m}$ from one another (Figure 3). Close to the wells and the rivers, the mesh has a variable, refined spacing. The internal contours are the wells and rivers, and the external borders is the watershed boundaries (Figure 3).

The initial potentiometric surface was created from the interpolation of the measured phreatic levels (Figure 4). Figure 4 shows the flow map in ROW, representing the element velocities by vectors. The spatial velocity distribution confirms the consistency of the model, once regions with unrealistic drainage values or drastic direction changes were not identified (Figure 4). The map also shows boundary areas in which lateral flows were considered in the aquifer.

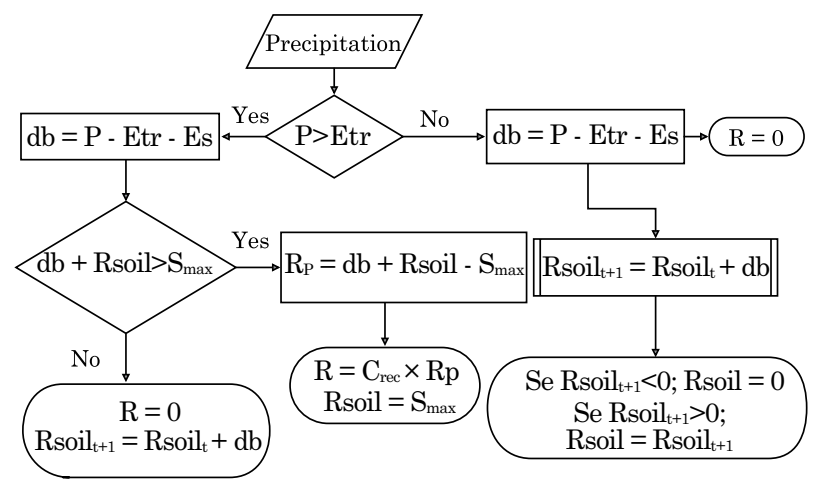

Figure 2. Conceptual scheme for the recharge estimate based on water balance.

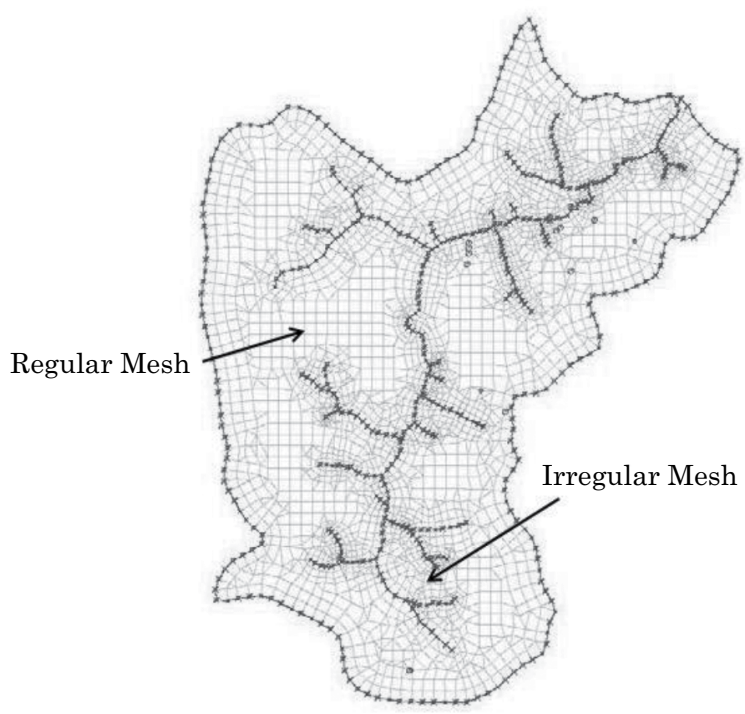

Figure 3. Discretization of the model domain in a finite element mesh.
Based on geological, hydrogeological and soil properties, as well as estimates of other GAS areas, presented by Sracek and Hirata (2002) and Gastmans and Kiang (2005), the initial value of $\mathrm{K}=4.32 \mathrm{~m} \mathrm{~d}^{-1}\left(5 \times 10^{-5} \mathrm{~m} \mathrm{~s}^{-1}\right)$ was adopted. This initial estimate was modified throughout the calibration process and spatialized based on the pedological map of the area. The magnitude of the final $\mathrm{K}$ values $\left(1.3 \times 10^{-6}\right.$ to $\left.2.6 \times 10^{-5} \mathrm{~m} \mathrm{~s}^{-1}\right)$ are in the order of the intervals found by Sracek and Hirata (2002) $\left(2 \times 10^{-6}\right.$ to $\left.1.9 \times 10^{-3} \mathrm{~m} \mathrm{~s}^{-1}\right)$ in the State of São Paulo.

Specific yield values obtained by Gomes (2008) for the study area are between 8.5 and $15.9 \%$. These results are similar to the ones found by Sracek and Hirata (2002) for the GAS regions (7 a $15 \%$ ). To specify the porosity, the influence areas specified by Gomes (2008) were considered. They were obtained as a function of the average thickness of the unsaturated layer and the distance of the collection points from the water stream.

The attributions made to the RIOS field are related to the representation of ranges, in which the aquifer surface is practically outcropping, and, in the rainy season, give rise to springs. In these parts with high evapotranspiration rates, the third boundary condition was applied.

This adjustment considered that the highly elevated fixed potentials may cause, over time, a rise in the levels (even without recharge increase), because they function as water sources of the aquifer. Over time, very low fixed potentials result in a lowering of the levels (also without alteration in recharge), since a high hydraulic gradient

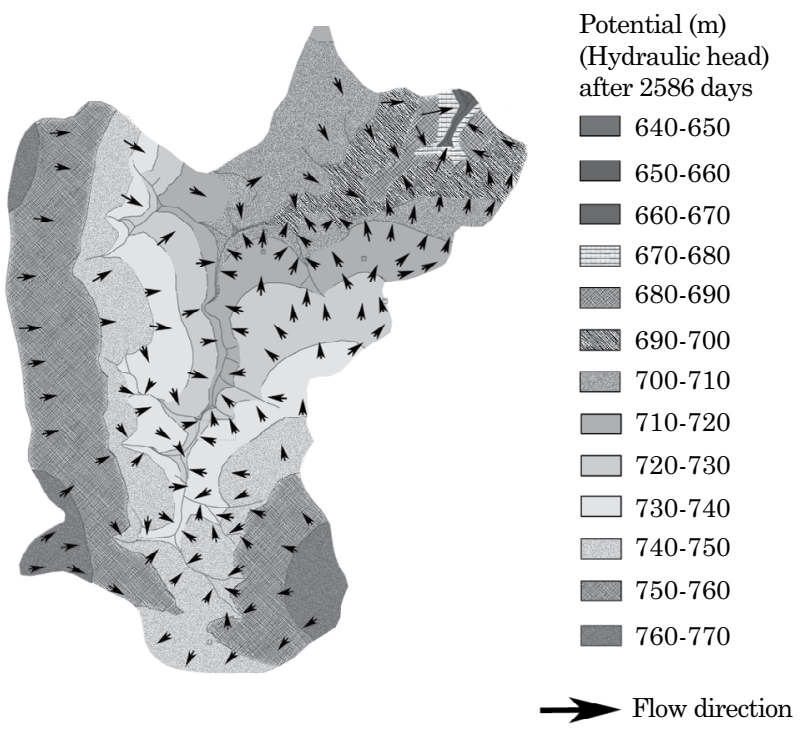

Figure 4. Potentiometric surface obtained after running the model. Vectors in black represent the Darcy velocities. 
opposite to the river flow is imposed, which begins to function as a sink.

\section{Recharge estimation}

Recharge rates were calculated on a monthly scale, applying the water balance proposed in the methodology for different land use types (Figure 5). Total monthly rainfall registered at the stations ANA and CRHEA are shown in figure 5. Importantly, spatial variability in rainfall must not be ignored. Pedersen et al. (2010) observed significant differences (variation coefficient of up to $77 \%$ ) in an area of $0.25 \mathrm{~km}^{2}$. Correlation values lower than 0.5 were found for rainfall series measured $10 \mathrm{~km}$ apart (Tokay et al., 2014).

Even at a distance of less than $10 \mathrm{~km}$ between the stations ANA and CRHEA, there are significant differences in some months, e.g., in January 2011, the pluviometer at ANA registered almost $100 \mathrm{~mm}$ more rain. These differences were detectable when comparing the recharge results estimated by the water balance method and those presented by Lucas et al. (2012) on an annual scale.

The referred comparison is shown in figure 6 , where greatest differences are observed between the estimates for areas of pasture and plantation in $2009(\sim 100 \mathrm{~mm})$ and $2010(\sim 120 \mathrm{~mm})$, respectively. A possible explanation for these discrepancies is the spatial variability in rainfall. As shown by the weather station data for the study area, and by Tokay et al. (2014) and Pedersen et al. (2010), the totality of a given rainfall may not be recorded in areas close to the measuring site. Depending on the rainfall series used to generate the water balance (WB), substantially distinct recharge rates are found.

Differences between recharge values estimated by the methods WTF and WB can be explained by the uncertainty related to the input variables of the methods. In the case of WTF, an essential parameter in the equation is the specific yield $\left(\mathrm{S}_{\mathrm{y}}\right)$

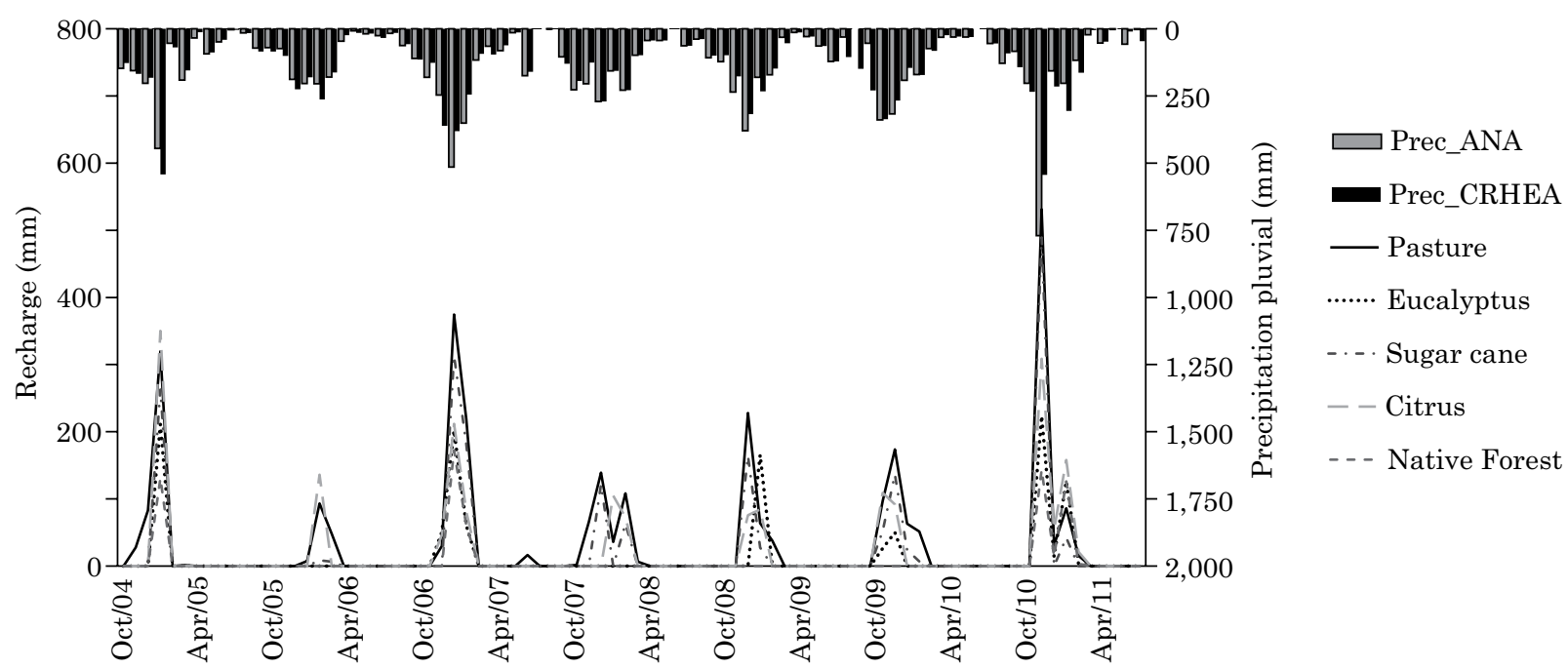

Figure 5. Monthly recharge rates (colored lines) obtained by the Water Balance method using total rainfall from the weather stations ANA and CRHEA (vertical bars).

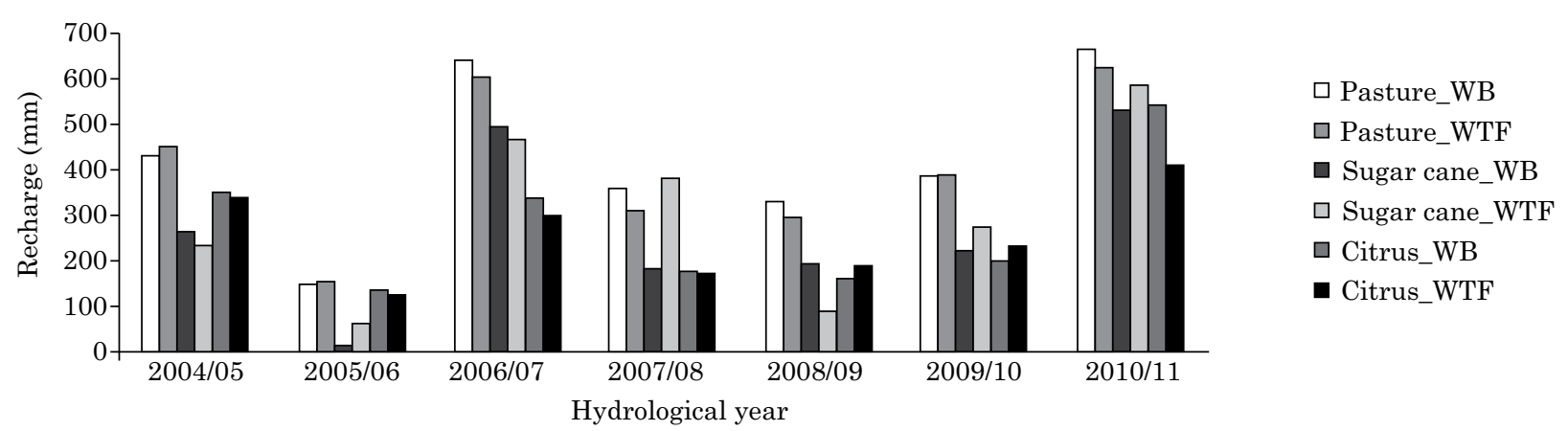

Figure 6. Comparison between $y$ the annual recharge rates obtained by the Water Balance and Water Table Fluctuation (WTF) methods. 
related to soil porosity. This parameter is hard to determine and usually varies according to the depth, due to the heterogeneity of natural soils. In the case of WBM, the variable with greatest uncertainty is evapotranspiration (ET), whose definition depends on climatic variables and crop coefficients, adopted from values cited in the literature.

\section{Model calibration - TP Module}

The transient simulation of the model was made using module TP of SPA, and the distributed values of the monthly recharge rates estimated by the water balance as input (Figure 7). The results were stored on a monthly basis between 2004 and 2010 (0 to 2500 days). For each simulation, the software generated deviation reports. The average and maximum deviations computed for each node corresponding to the monitoring wells (Table 1).

The calibration was more difficult in the second year of simulation, since the observed levels do practically not respond to the rainfall events, reaching a maximum difference of $1.80 \mathrm{~m}$ in relation to what is simulated in P13. For this node, the average error $(0.59 \mathrm{~m})$ was slightly higher to the one found for P14 $(0.58 \mathrm{~m})$. These differences can indicate that the recharge rates calculated for the respective periods are under or overestimated by the adopted method.

Despite the adjustments, the model is still a simplification of the real processes and, therefore, contains limitations which, in this study, could be identified close to the boundary conditions. The node referring to well $16(\mathrm{P} 16)$ is found on the border between mesh elements that refer to the native forest and pasture.

In the rainy season, the aquifer level rises close to the surface or emerges to the marginal river areas. With this, losses by direct transpiration rise, and due to the complexity of their incorporation in the water balance to estimate the recharge, the model responds with a damming effect, expressed in peaks exceeding the observed values. Still, for the remaining period, the simulated are satisfactorily close to the measured levels, with an average error lower than $0.5 \mathrm{~m}$ in wells 16 and 17.

Table 1. Maximum and mean errors at the nodes used in the calibration of the numerical model for the Ribeirão da Onça watershed

\begin{tabular}{|c|c|c|}
\hline \multirow{2}{*}{ Node corresponding to well } & \multicolumn{2}{|c|}{ Error } \\
\hline & Maximum & Average \\
\hline & \multicolumn{2}{|c|}{$\mathrm{m}$} \\
\hline 05 & 0.95 & 0.32 \\
\hline 13 & 1.80 & 0.59 \\
\hline 14 & 1.53 & 0.58 \\
\hline 15 & 1.30 & 0.39 \\
\hline 16 & 1.34 & 0.31 \\
\hline 17 & 1.35 & 0.47 \\
\hline 18 & 2.29 & 0.93 \\
\hline 19 & 3.05 & 0.95 \\
\hline
\end{tabular}
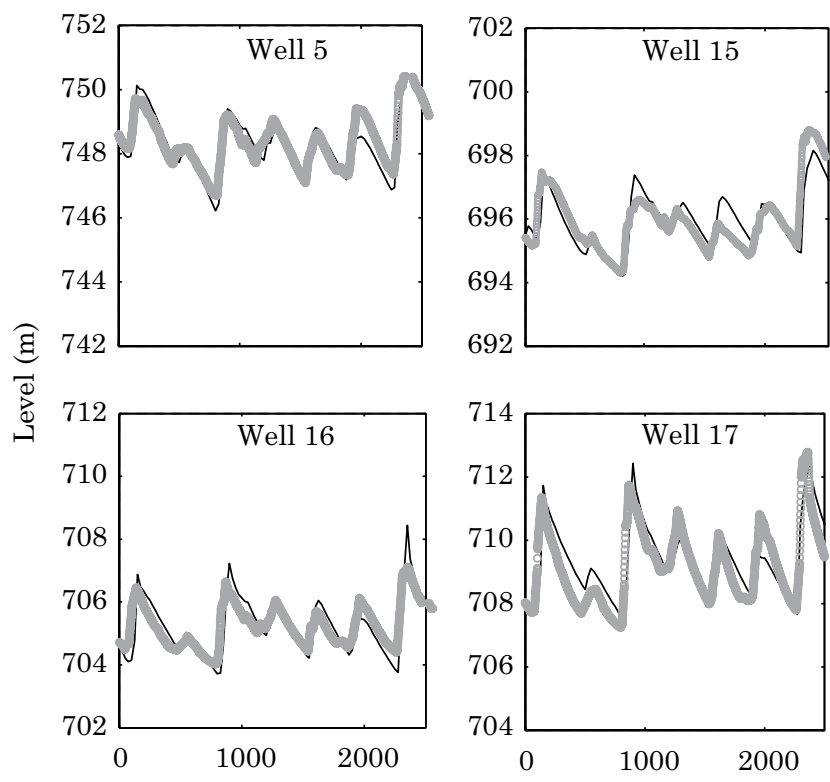

Time (day)
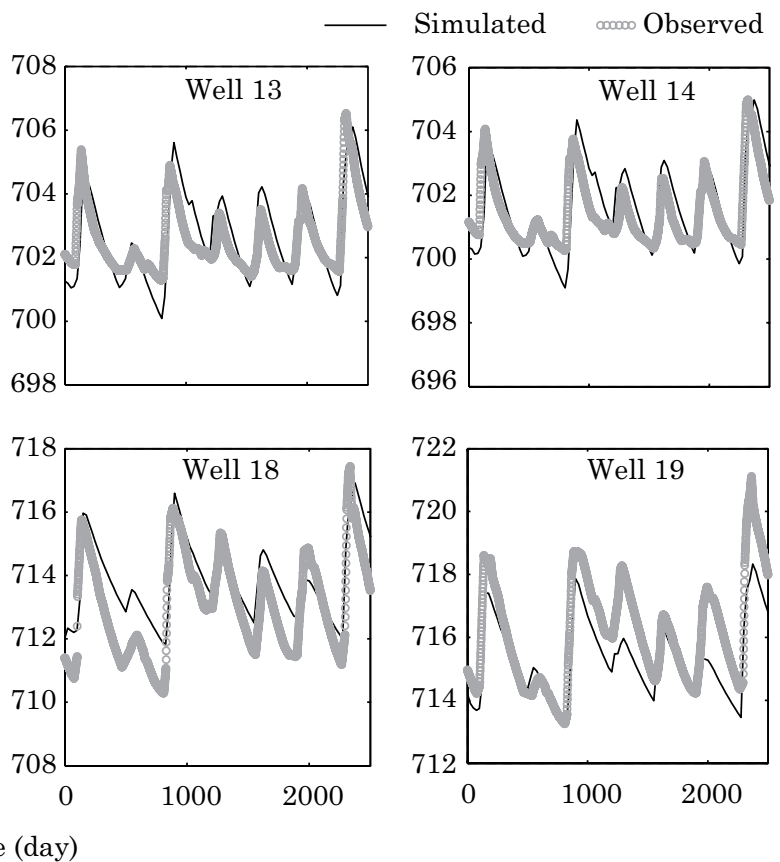

Figure 7. Results from model calibration. Measured levels in red and SPA-simulated levels in black. 


\section{CONCLUSIONS}

Results of recharge estimated by water balance in the unsaturated soil zone were similar to the previously obtained by the WTF method. The differences between the estimates were lower than $50 \mathrm{~mm}$ in more than $60 \%$ of the cases.

The greater differences between the $\mathrm{BH}$ and WTF responses are related to the intrinsic limitations of the methods, spatial variability of rainfall and uncertainties in the input data.

Although groundwater recharge cannot be directly measured to validate the estimates established indirectly by different methods (e.g., WTF or Water Balance), a similar verification or comparison of the simulated to the measured levels can be performed in loco using a numerical model of transient flow.

The calibration of the numerical model evidenced the influence of the most distinct hydrogeological parameters, and reinforced the importance of compiling more spatial information to characterize the study area in greater detail, thus reducing uncertainties in modeling.

Computational models can be used not only to control the recharge estimates, but also to deepen the understanding of processes occurring in the study area, or even allow an evaluation of the impact of different climatic scenarios at the aquifer levels.

\section{REFERENCES}

Allen GR, Pereira LS, Raes D, Smith M. Crop Evapotranspiration (guidelines for computing crop water requirements). Rome: Food and Agriculture Organization of the United Nations; 1998. (FAO Irrigation and Drainage Paper, 56).

Araújo LM, França AB, Potter PE. Hydrogeology of the Mercosul aquifer system in the Paraná and Chaco-Paraná Basins, South America, and comparison with the Navajo-Nugget aquifer system, USA. Hydrogeol J. 1999;7:317-36.

Barrett R, Berry M, Chan TC, Demmel J, Donato J, Dongarra J, Eijkhout V, Pozo R, Romine C, van der Vorst H. Templates for the solution of linear systems: building blocks for iterative methods. $2^{\text {nd }}$. ed. Philadelphia [PA]: SIAM; 1994.

De Vries J, Simmers I. Groundwater recharge: an overview of processes and challenges. Hydrogeol J. 2002;10:5-17.

Gastmans D, Kiang CH, Hutcheon I. Stable isotopes $\left({ }^{2} \mathrm{H},{ }^{18} \mathrm{O}\right.$ and ${ }^{13} \mathrm{C}$ ) in groundwaters from the northwestern portion of the Guarani Aquifer System (Brazil). Hydrogeol J. 2010;18:1497-513.

Gastmans D, Kiang CH. Avaliação da hidrogeologia e hidroquímica do Sistema Aquífero Guarani (SAG) no estado do Mato Grosso do Sul. Águas Subt. 2005;19:35-48.

George PL, Seveno E. The advancing-front mesh generation method revisited. Int J Numer Meth Eng. 1994;37:3605-19.
Gomes LH. Determinação da recarga profunda na bacia-piloto do Ribeirão da Onça em zona de afloramento do Sistema Aquífero Guarani a partir de balanço hídrico em zona saturada [dissertação]. São Carlos: Universidade de São Paulo; 2008

Healy R, Cook P. Using groundwater levels to estimate recharge. Hydrogeol J. 2002;10:91-109.

Healy RW, Winter TC, Labaugh JW, Franke O. Water budgets: foundations for effective water-resources and environmental management. Reston, Virginia: U.S. Geological Survey; 2007. (Circular, 1308).

Kwon HH, Souza Filho FA, Block P, Sun L, Lall U, Reis DS. Uncertainty assessment of hydrologic and climate forecast models in Northeastern Brazil. Hydrol Process. 2012;26:3875-85.

Lucas MC, Guanabara RC, Wendland E. Estimating groundwater recharge in the outcrop area of the Guarani Aquifer System. B Geol Min. 2012;123:311-23.

Machado AR, Wendland E, Krause P. Improving water balance in an outcrop area of the Guarani Aquifer System through hydrologic simulation. Environ Process. 2014 (Submitted).

Manzione R, Tanikawa DH, Wendland E. Análise de tendências nos níveis freáticos de uma bacia hidrográfica em área de recarga do Sistema Aquífero Guarani (SAG) auxiliado por imagens de sensoriamento remoto, sistemas de preparo de solo: alterações na estrutura do solo e rendimento das culturas. In: Anais do $15^{\circ}$ Simpósio Brasileiro de Sensoriamento Remoto; 2011; São José dos Campos. São José dos Campos: INPE; 2011. p.1-17.

Medeiros PV, Marcuzzo FFN, Youlton C, Wendland E. Error autocorrelation and linear regression for temperature-based evapotranspiration estimates improvement. J Am Water Res Assoc. 2012;48:297-305.

Melo DCD. Estimativa de impacto de mudanças climáticas nos níveis do aquífero livre em zona de recarga do Sistema Aquífero Guarani [dissertação]. São Carlos: Universidade de São Paulo, 2013.

Organização dos Estados Americanos - OEA. Programa Estratégico de Ação do Projeto de Proteção Ambiental e Desenvolvimento Sustentável do Sistema Aquífero Guarani [Relatório técnico]. 2009.

Pedersen L, Jensen NE, Christensen LE, Madsen H. Quantification of the spatial variability of rainfall based on a dense network of rain gauges. Atmos Res. 2010;95:441-54.

Raneesh KY, Thampi S. A simple semi-distributed hydrological model to estimate groundwater recharge in a humid tropical basin. Water Res Manage. 2013;27:1517-32.

Rodríguez L, Vives L, Gomez A. Conceptual and numerical modeling approach of the Guarani Aquifer System. Hydrol Earth Syst Sci. 2013;17:295-314.

Scanlon BR, Healy R, Cook P. Choosing appropriate techniques for quantifying groundwater recharge. Hydrogeol J. 2002;10:347-21.

Scanlon BR, Keese KE, Flint AL, Flint LE, Gaye CB, Edmunds WM, Simmers I, Cook P. Global synthesis of groundwater recharge in semiarid and arid regions. Hydrol Process. 2006;20:3335-70

Sracek O, Hirata R. Geochemical and stable isotopic evolution of the Guarani Aquifer System in the state of Sao Paulo, Brazil. Hydrogeol J. 2002;10:643-55. 
Tokay A, Roche RJ, Bashor PG. An experimental study of spatial variability of rainfall. J Hydrometeor. 2014;15:801-12.

Wendland E, Barreto C, Gomes LH. Water balance in the Guarani Aquifer outcrop zone based on hydrogeologic monitoring. J Hydrol. 2007;342:261-9.

Wendland E, Gomes LH, Troeger U. Recharge contribution to the Guarani Aquifer System estimated from the water balance method in a representative watershed. An Acad Bras Ci. 2014;87:595-609.
Wendland E, Rabelo JL. Incertezas nos modelos de fluxo subterrâneo. R Bras Rec Hídric. 2010;15:147-60.

Wendland E, Simonato MD, Lapiccirella ES, Hirata R. Modelo numérico de escoamento subterrâneo na região de São José do Rio Preto, São Paulo-SP. Águas Subt. 2013;27:92-109.

Wendland E. Implementação de pacote computacional SPA (Simulação de Processos em Aquíferos). São Paulo: Universidade de São Paulo; 2003. (Relatório Técnico de Pesquisa FAPESP 02/09696-3). 